\title{
DISSIMILAR SPOT WELDING OF DQSK/DP600 STEELS: THE WELD-NUGGET GROWTH
}

\author{
TOČKASTO VARJENJE JEKEL DQSK/DP600: RAST JEDRA ZVARA
}

\author{
Seyed Pirooz Hoveida Marashi \\ Amirkabir University of Technology, Mining and Metallurgical Engineering Department, Tehran, Iran \\ pmarashi@aut.ac.ir \\ Prejem rokopisa - received: 2015-07-30; sprejem za objavo - accepted for publication: 2015-10-12
}

doi:10.17222/mit.2015.241

\begin{abstract}
The weld-nugget size is the key issue in determining the mechanical properties of resistance spot welds. This paper aims at investigating the weld-nugget growth of dissimilar-resistance spot welding of ferrite-martensite DP600 and drawing-quality special-killed (DQSK) low-carbon steel. It was revealed how the weld-nugget size is influenced by the main welding parameters: welding current, welding time and electrode force. The weldability lobe was established and proper welding conditions for the welds with a sufficient size and without an expulsion were determined. Using the experimental data, an empirical relationship between the weld-nugget size and the welding parameters was developed.

Keywords: resistance spot welding, dual-phase steel, dissimilar welding, weld-nugget growth

Velikost jedra zvara je ključnega pomena pri določanju mehanskih lastnosti uporovnih točkastih zvarov. Namen tega članka je preiskava rasti jedra zvara pri točkastem uporovnem varjenju feritno-martenzitnega DP600 in pomirjenega malogljičnega jekla DQSK za globoki vlek. Ugotovljeno je bilo, kako na velikost jedra zvara vplivajo glavni parametri varjenja: varilni tok, čas varjenja in pritisk elektrode. Vzpostavljen je bil varilni kiln in določeni so bili pravilni varilni pogoji za izdelavo dovolj velikih zvarov, brez izgonov taline. Z uporabo eksperimentalnih podatkov je bila postavljena empirična odvisnost med velikostjo jedra zvara in parametri varjenja.

Ključne besede: uporovno točkasto varjenje, dvofazno jeklo, varjenje različnih materialov, rast jedra zvara
\end{abstract}

\section{INTRODUCTION}

Resistance spot welding is considered as the dominant process for joining sheet metals in the automotive industry. Simplicity, low cost, high speed (low process time) and automation possibility are the advantages of this process. The quality and mechanical behavior of spot welds significantly affect the durability and crashworthiness of a vehicle. ${ }^{1-3}$ To ensure and maintain the structural integrity of a finished component under a wide range of operating conditions, e.g., a crash situation, a remotest possibility of producing even one or two defective welds in a critical component needs to be eliminated. These requirements, coupled with the uncertainties about the weld quality due to the difficulty of applying nondestructive tests to spot welds, are responsible for the practice of making more spot welds than needed for maintaining the structural integrity. Typically, there are about 2000-5000 spot welds in a modern vehicle. Around 20-30 \% of these spot welds are due to the uncertainty of the quality of spot welds. A significant cost associated with over-welding provides a considerable driving force for optimizing this process. ${ }^{4}$

Resistance spot welding is a process of joining two or more metal parts using fusion at discrete spots at the interface of workpieces. The resistance to the current flow through the metal workpieces and their interface generates heat; therefore, the temperature rises at the interface of the workpieces. When the melting point of the metal is reached, the metal will begin to fuse and a nugget begins to form. The current is then switched off and the nugget is cooled down to solidify under pressure. $^{5,6}$

It is well established that the geometrical attributes of spot welds, particularly the weld-nugget size, are the most important controlling factors determining the mechanical strength of RSWs. ${ }^{7-12}$ In this regard, the weld-nugget size was included in several empirical relations. For example, J. Heuschkel ${ }^{13}$ developed empirical relations among the tensile-shear strength $(P)$, weldnugget diameter $(D)$, base-metal tensile strength $\left(\sigma_{\mathrm{BM}}\right)$, sheet thickness $(t)$ and base-metal chemical composition (C, Mn):

$$
P=D t[\alpha-\beta(C+0.05 \mathrm{Mn})] \sigma_{\mathrm{BM}}
$$

where $\alpha$ and $\beta$ are material-dependent coefficients. Similar relations were developed by other researchers. For example, the following relation was developed by $\mathrm{J}$. M. Sawhil and J. C. Baker ${ }^{14}$ for the tensile-shear strength of spot welds:

$$
P=f t D \sigma_{\mathrm{BM}}
$$

where $f$ is a material-dependent coefficient, with a value between 2.5 and 3.1 .

Considering the importance of the weld-nugget size for the quality of spot welds, there is a need to study the 
effects of RSW parameters such as welding current, electrode force and welding time on this key physical weld attribute. Moreover, an increased use of advanced high-strength steels (AHSS), particularly ferrite-martensite DP steels, led to a wider range of possible material combinations in the resistance spot welding (RSW) of body-in-white assemblies. Therefore, there is clearly a practical need for the study of the weld-nugget growth during the RSW of dissimilar steel grades. In this paper, weld-nugget growth characteristics of dissimilar RSW of ferrite-martensite DP600 and drawing-quality specialkilled (DQSK) low-carbon steel are investigated. The aim of this paper is to reveal how the weld-nugget size is influenced by the main welding parameters: welding current, welding time and electrode force.

\section{EXPERIMENTAL PROCEDURE}

2-mm-thick drawing-quality special-killed (DQSK) low-carbon steel and 2-mm-thick DP600 dual-phase steel sheets were used as the base metals. The chemical compositions of the base metals are shown in Table $\mathbf{1}$. Resistance spot welding was performed using a PLCcontrolled, $120 \mathrm{kVA}$ AC pedestal-type resistance-spotwelding machine. The welding was conducted using a 45-deg truncated-cone RWMA Class 2 electrode with an 8-mm face diameter.

Table 1: Chemical compositions of steels used in this study Tabela 1: Kemijska sestava jekel, uporabljenih v študiji

\begin{tabular}{|c|c|c|c|c|c|}
\hline Base metal & $\mathrm{C}$ & $\mathrm{Mn}$ & $\mathrm{Si}$ & $\mathrm{S}$ & $\mathrm{P}$ \\
\hline DP600 & 0.035 & 1.08 & 0.388 & 0.004 & 0.038 \\
\hline LCS & 0.065 & 0.204 & 0.095 & 0.017 & 0.018 \\
\hline
\end{tabular}

To study the effects of the welding conditions (welding current, welding time and electrode force) on the weld failure mode, several welding schedules were used. Figure 1 shows a schematic of the welding schedules used in this study. A total of 60 combinations of the welding current, the welding time and the electrode force were performed.

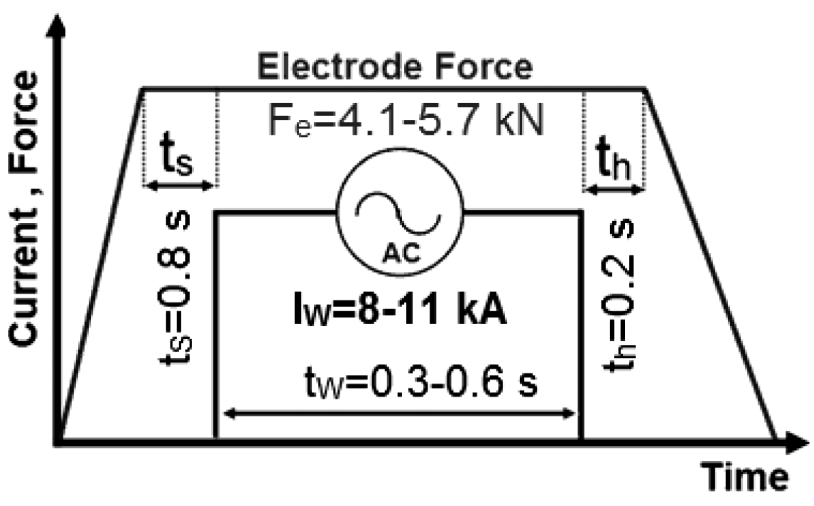

Figure 1: Schematic of the welding schedules used in this study Slika 1: Shema časovnega poteka varjenja v tej študiji
Samples for the metallographic examination were prepared using the standard metallographic procedure. Light microscopy was used to examine the macrostructures and microstructures and to measure the weld fusion zone (weld nugget). The samples for the metallographic examination were prepared using the standard metallographic procedure. A $4 \%$ Nital etching reagent was used to reveal the macrostructures of the samples. The FZ size is defined as the width of the weld nugget at the sheet/sheet interface in the longitudinal direction. The indentation depth is expressed as the percentage of the sheet thickness.

\section{RESULTS AND DISCUSSION}

\subsection{Weld macrostructure}

Figure 2 shows the macrostructure of a weld joining DP600 and low-carbon steel indicating that there are three distinct microstructural zones:

1) The weld nugget $(\mathrm{WN})$ or fusion zone (FZ) which is melted during the welding process and then resolidified showing a cast structure. The macrostructure of the weld nugget consists of columnar grains.

2) The heat-affected zone (HAZ) which does not melted but undergoes microstructural changes.

3) The base metal (BM).

\subsection{Effects of the welding parameters on the weld- nugget growth}

The effects of welding parameters on the weldnugget size are shown in Table 2. Contour plots for the weld-nugget size versus the welding current and the welding time at three levels of the electrode force are shown in Figure 3. According to these results, the following points can be drawn:

1) The welding current has a profound effect on the weld-nugget growth. Increasing the welding current increases the weld-nugget size.

2) Increasing the welding time increases the weldnugget size.

3) Increasing the electrode force decreases the weldnugget size. Indeed, when applying electrode force,

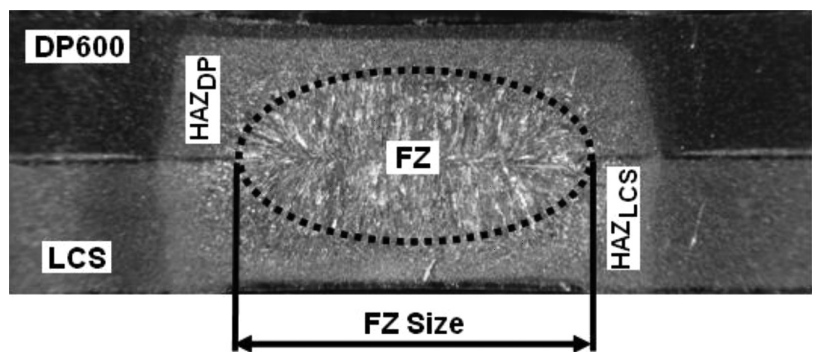

Figure 2: Macrostructure of a weld of DP600 and low-carbon steel: FZ size is defined as the width of the weld nugget at the sheet/sheet interface in the longitudinal direction

Slika 2: Makrostruktura zvara DP600 in maloogljičnega jekla: FZ je širina pretaljenega jedra na stiku pločevin v vzdolžni smeri 

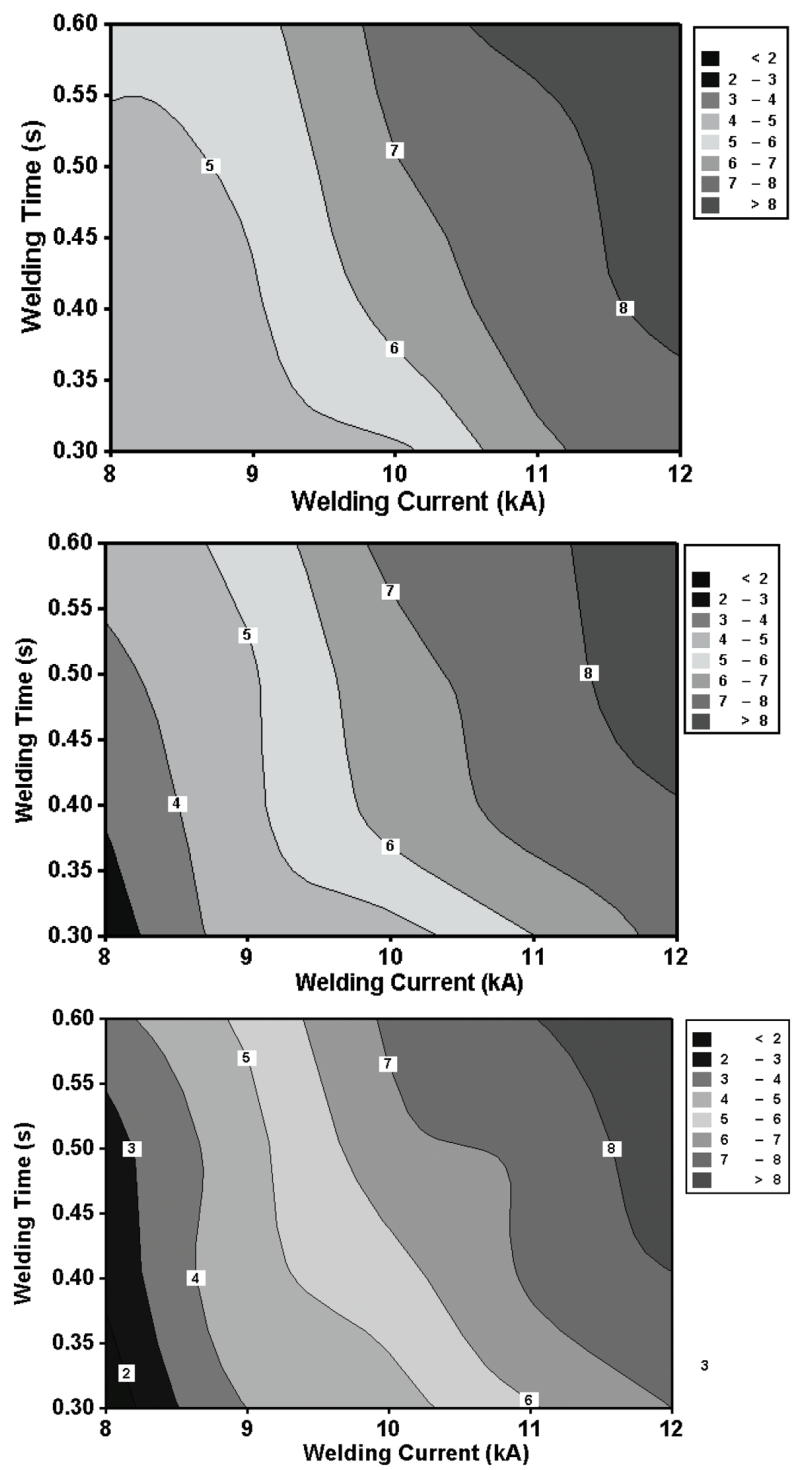

Figure 3: Weld-nugget size versus welding time and welding current at electrode forces of: a) $4.1 \mathrm{kN}$, b) $5.1 \mathrm{kN}$ and c) $5.7 \mathrm{kN}$

Slika 3: Velikost pretaljenega jedra zvara v odvisnosti od časa varjenja in varilnega toka pri sili elektrode: a) $4,1 \mathrm{kN}$, b) $5,1 \mathrm{kN}$ in c) $5,7 \mathrm{kN}$

there is need to use higher welding current and welding time to obtain a specific weld-nugget size.

The amount of heat generated at the sheet-to-sheet interface during the spot-welding process is the main reason for the nugget formation and its strength. The heat generated during the resistance spot welding can be expressed as follows:

$$
Q=R I_{\mathrm{w}}^{2} t_{\mathrm{W}}
$$

where $Q, R, I_{\mathrm{w}}$ and $t_{\mathrm{w}}$ are the generated heat, the electrical resistance, the welding current and the welding time, respectively.

Therefore, the three main parameters affecting the weld-nugget growth are the welding current, the welding time and the electrical resistance. The heat varies directly with the interface resistance, the welding time and the
Table 2: Effects of welding current and welding time on the weldnugget size at three different electrode forces (S: small, A: acceptable, E: expulsion)

Tabela 2: Vpliv varilnega toka in časa varjenja na velikost pretaljenega jedra pri treh različnih pritiskih elektrod

\begin{tabular}{|c|c|c|c|c|}
\hline \multirow{2}{*}{$\begin{array}{c}\text { Welding } \\
\text { current } \\
(\mathrm{kA})\end{array}$} & \multirow{2}{*}{$\begin{array}{c}\text { Welding } \\
\text { time }(\mathrm{s})\end{array}$} & \multicolumn{3}{|c|}{ Weld-nugget size $(\mathrm{mm})$} \\
\cline { 3 - 5 } & 0.3 & $4.35(\mathrm{kN})$ & $2.3(\mathrm{~S})$ & $1.2(\mathrm{~S})$ \\
\hline 8 & 0.4 & $4.67(\mathrm{~S})$ & $3.15(\mathrm{~S})$ & $2.2(\mathrm{~S})$ \\
\hline 8 & 0.5 & $4.9(\mathrm{~S})$ & $3.8(\mathrm{~S})$ & $2.6(\mathrm{~S})$ \\
\hline 8 & 0.6 & $5.12(\mathrm{~S})$ & $4.24(\mathrm{~S})$ & $3.7(\mathrm{~S})$ \\
\hline 8 & 0.3 & $4.8(\mathrm{~S})$ & $4.4(\mathrm{~S})$ & $4(\mathrm{~S})$ \\
\hline 9 & 0.4 & $4.9(\mathrm{~S})$ & $4.8(\mathrm{~S})$ & $4.65(\mathrm{~S})$ \\
\hline 9 & 0.5 & $5.25(\mathrm{~S})$ & $4.9(\mathrm{~S})$ & $4.67(\mathrm{~S})$ \\
\hline 9 & 0.6 & $5.73(\mathrm{~A})$ & $5.4(\mathrm{~S})$ & $5.22(\mathrm{~S})$ \\
\hline 9 & 0.3 & $4.85(\mathrm{~S})$ & $4.55(\mathrm{~S})$ & $4.55(\mathrm{~S})$ \\
\hline 10 & 0.4 & $6.3(\mathrm{~A})$ & $6.35(\mathrm{~A})$ & $5.6(\mathrm{~A})$ \\
\hline 10 & 0.5 & $6.95(\mathrm{~A})$ & $6.65(\mathrm{~A})$ & $6.6(\mathrm{~A})$ \\
\hline 10 & 0.6 & $7.35(\mathrm{~A})$ & $7.25(\mathrm{~A})$ & $7.1(\mathrm{~A})$ \\
\hline 10 & 0.3 & $6.75(\mathrm{~A})$ & $6(\mathrm{~A})$ & $5.9(\mathrm{~A})$ \\
\hline 11 & 0.4 & $7.5(\mathrm{~A})$ & $7.3(\mathrm{~A})$ & $7.1(\mathrm{~A})$ \\
\hline 11 & 0.5 & $7.55(\mathrm{~A})$ & $7.5(\mathrm{~A})$ & $7.2(\mathrm{~A})$ \\
\hline 11 & 0.6 & $8.5(\mathrm{~A})$ & $7.75(\mathrm{~A})$ & $7.95(\mathrm{~A})$ \\
\hline 11 & 0.3 & $7.65(\mathrm{E})$ & $7.35(\mathrm{E})$ & $7(\mathrm{E})$ \\
\hline 12 & 0.4 & $8.2(\mathrm{E})$ & $7.95(\mathrm{E})$ & $7.95(\mathrm{E})$ \\
\hline 12 & 0.5 & $9(\mathrm{E})$ & $8.95(\mathrm{E})$ & $8.75(\mathrm{E})$ \\
\hline 12 & 0.6 & $8.8(\mathrm{E})$ & $8.9(\mathrm{E})$ & $8.9(\mathrm{E})$ \\
\hline 12 & & & & \\
\hline
\end{tabular}

second power of the welding current. Again, this contact (interface) resistance varies in a complex manner and it is influenced by the electrode force, the surface conditions of the sheets used and also by the geometry of the electrode tip.

Increasing the welding current and the welding time increases the heat generation, which in turn, causes an enlargement of the weld nugget.

The static electrical resistance (i.e., the contact resistance) is mainly governed by the electrode force, which in turn controls the weld-nugget formation. ${ }^{15}$ On a ductile material, where a normal force is applied across the contact interface, the number of surface asperities supporting the applied load gradually increases due to their successive yielding. In other words, the true contact area will initially be a relatively small fraction of the macroscopic, or apparent, contact area. Later, the true contact area will increase with the application of load and, in the limit, approach the apparent contact area. ${ }^{8}$ Therefore, an increase in the electrode force decreases the electric resistance and thus reduces the generated heat at the sheet/sheet interface.

Since the generated heat is proportional to the squared current, the current to the duration and the contact resistance is inversely proportional to the electrode force, another parameter, the so-called heat factor, can be defined as follows:

$$
\text { Heat factor }=\frac{I_{\mathrm{w}}^{2} t_{\mathrm{w}}}{F_{\mathrm{e}}}
$$




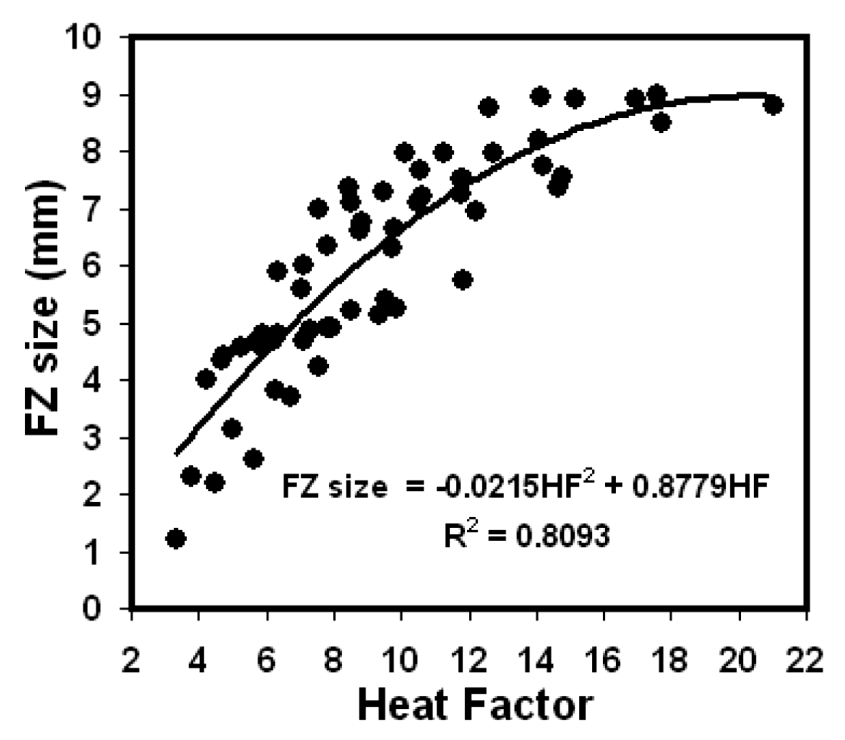

Figure 4: Weld-nugget size versus heat factor (HF)

Slika 4: Velikost pretaljenega jedra zvara v odvisnosti od faktorja toplote (HF)

where $F_{\mathrm{e}}$ is the electrode force. It is expected that the higher the heat factor, the higher is the weld-nugget size. As it can be seen in Figure 4, the weld-nugget growth is proportional to the heat factor, with the exception of high heat factors. This can be explained with the fact that increasing the heat factor increases the probability of expulsion. Expulsion can increase the heat losses. Therefore, increasing the heat factor beyond the critical value does not increase the weld-nugget size. Therefore, it can be concluded that there is not a proportional relationship between the heat factor and the weld-nugget size. This is important when selecting the optimum welding condition to obtain a larger weldnugget size.

\subsection{Quantitative relation between welding parameters and the weld-nugget size}

To establish a relationship between the weld-nugget size and the welding parameters, viz., the welding time, the welding current and the electrode force, the following relation was developed using multiple regression:

Weld Nugget Size $=0.62524+1.182121 I_{\mathrm{W}}+$

$+5.69533 t_{\mathrm{W}}-3.07395 F_{\mathrm{e}}+0.2568 I_{\mathrm{W}} F_{\mathrm{e}}-0.063452 I_{\mathrm{W}}^{2}$

In Figure 5, the values of the weld-nugget size obtained experimentally are plotted against the weldnugget size predicted with Equation (5). As can be seen, there is very little scatter of the points from the proposed equation. Deviations are well within the $95 \%$ confidence limit.

The ability to make a weld, based on the welding parameters and under production conditions, is best defined in terms of a 'weldability lobe'. The weldability lobe defines the available tolerances for producing a weld of a defined quality. In this way, it is possible to

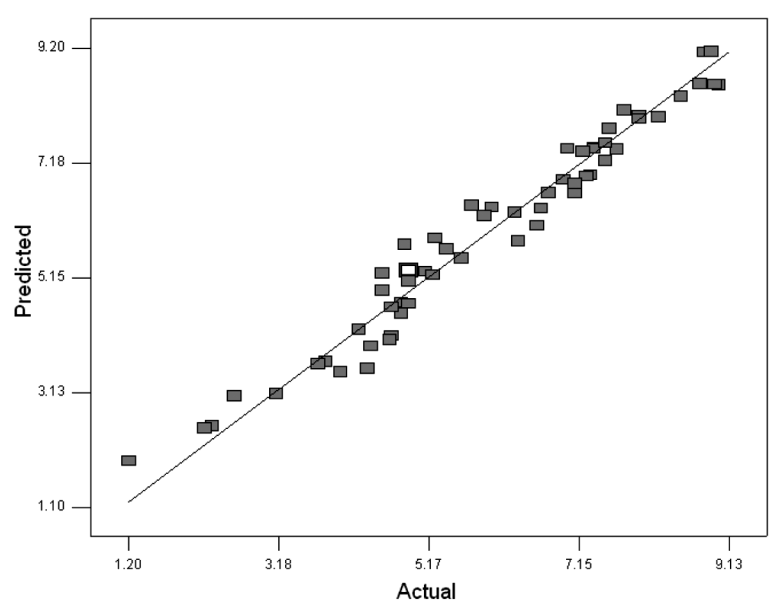

Figure 5: Scatter plot for the weld-nugget size

Slika 5: Diagram raztrosa velikosti staljenega jedra zvara

determine the welding parameters that allow an acceptable weld quality as defined with precise physical limits, such as the weld size, or non-marking or aesthetic qualities, associated with the amount of surface indentation. ${ }^{4}$ According to the AWS D8.1M standard ${ }^{16}$ for automotive weld-quality resistance spot welding of steels, the lower limit of a lobe diagram corresponds to the welding condition leading to the welds with the nugget size larger than $4 t^{0.5}$, where $\mathrm{t}$ is the sheet thickness. The upper limits outlining the tolerance box for acceptable welding are generally defined in terms of the weld-nugget expulsion.

In Table 2, the range of the welding parameters producing reliable spot welds is highlighted in blue. The welding condition producing small welds is in gray. Also, the expulsion occurrence is highlighted in red. The suitable welding-current range is from the current, under which the minimum nugget diameter (for example, $4 t^{0.5}$ ) is formed to that, under which the expulsion occurs. A wide suitable welding-current range is desirable because it is possible to control the nugget diameter within a prescribed range even if the welding current fluctuates. The welding range for each welding time is about $2 \mathrm{kA}$, which is a proper welding-current range indicating good weldability.

\section{CONCLUSIONS}

Understanding the influence of RSW parameters on the weld-nugget growth during resistance spot welding is a prerequisite for the development of the optimum welding conditions, ensuring high levels of joint quality in auto-body manufacture. The results of the present research revealed how the weld-nugget size is influenced by the main welding parameters, viz., the welding current, the welding time and the electrode force:

1) Increasing the heat input caused by increasing the welding current and the welding time led to an enlargement of the weld nugget due to increasing the heat generated at the sheet/sheet interface. 
2) Increasing the electrode force can increase the initial sheet/sheet contact areas and therefore decrease the sheet/sheet interfacial electrical resistively, which in turn leads to a reduction in the generated heat at the sheet/sheet interface. In other words, increasing the electrode force increases the welding current and welding time required to melt the sheet/sheet interface.

3) We determined a relation involving the weld-nugget size and the welding parameters, viz., the welding current, the welding time and the electrode force. This helped us to evaluate the combined effect of the welding parameters on the weld-nugget size. Using such a quantitative relation, the selection of the optimum welding condition becomes straightforward.

4) Another factor, the heat factor $=I^{2} t / F$, was defined to evaluate the combining effect of the welding parameters on the weld-nugget size.

5) The weldability lobe for dissimilar-resistance spot welding of DP600 and low-carbon steel was determined using the established criteria of the AWS standard. A wide welding-current range was established indicating good weldability.

\section{REFERENCES}

${ }^{1}$ M. Pouranvari, H. R. Asgari, S. M. Mosavizadeh, P. H. Marashi, M Goodarzi, Effect of weld nugget size on overload failure mode of resistance spot welds, Sci. Technol. Weld. Joining, 12 (2007), 217-225, doi:10.1179/174329307x164409

${ }^{2}$ M. Pouranvari, Susceptibility to interfacial failure mode in similar and dissimilar resistance spot welds of DP600 dual phase steel and low carbon steel during cross-tension and tensile-shear loading conditions, Mater. Sci. Eng. A, 546 (2012), 129-138, doi:10.1016/ j.msea.2012.03.040

${ }^{3}$ M. Pouranvari, E. Ranjbarnoodeh, Dependence of Fracture Mode on Welding Variables in Resistance Spot Welding of DP980 Advanced High Strength Steel, Mater. Tehnol., 46 (2012), 665-671
${ }^{4}$ N. T. Williams, J. D. Parker, Review of resistance spot welding of steel sheets, Part 1: Modelling and control of weld nugget formation, International Materials Reviews, 49 (2004), 45-75, doi:10.1179/ 095066004225010523

${ }^{5}$ J. C. Feng, Y. R. Wang, Z. D. Zhang, Nugget growth characteristic for AZ31B magnesium alloy during resistance spot welding, Sci. Technol. Weld. Joining, 11 (2006), 154-162, doi:10.1179/ 174329306x84364

${ }^{6}$ M. Pouranvari, S. P. H. Marashi, Critical review of automotive steels spot welding: process, structure and properties, Sci. Technol. Weld. Joining, 18 (2013), 361-403, doi:10.1179/1362171813y.0000000120 ${ }^{7}$ H. Zhang, J. Senkara, Resistance welding: fundamentals and applications, Taylor \& Francis CRC Press, ........... 2005

${ }^{8}$ A. De, O. P. Gupta, L. Dorn, An experimental study of resistance spot welding in $1 \mathrm{~mm}$ thick sheet of low carbon steel, Proc. Inst. Mech. Engrs., Part B: Journal of Engineering Manufacture, 210 (1996), 341-347, doi:10.1243/pime_proc_1996_210_126_02

${ }^{9}$ M. Pouranvari, S. P. H. Marashi, On the failure of low carbon steel resistance spot welds in quasi-static tensile-shear loading, Materials \& Design, 31 (2010), 3647-3652, doi:10.1016/j.matdes.2010.02.044

${ }^{10}$ M. Pouranvari, S. P. H. Marashi, S. M. Mousavizadeh, Failure mode transition and mechanical properties of similar and dissimilar resistance spot welds of DP600 and low carbon steels, Science and Technology of Welding \& Joining, 15 (2010), 625-631, doi:10.1179/ 136217110x12813393169534

${ }^{11}$ M. Pouranvari, S. P. H. Marashi, Failure mode transition in AISI 304 resistance spot welds, Welding Journal, 91 (2012), 303-309

${ }^{12}$ M. Pouranvari, S. P. H. Marashi, Factors affecting mechanical properties of resistance spot welds, Materials Science and Technology, 26 (2010), 1137-1144, doi:10.1179/174328409x459301

${ }^{13} \mathrm{~J}$. Heuschkel, The expression of spot-weld properties, Welding Journal, 31 (1952), 931-943

${ }^{14}$ J. M. Sawhill, J. C. Baker, Spot weldability of high-strength sheet steels, Welding Journal, 59 (1980), 19-30

${ }^{15}$ Q. Song, W. Zhang, N. Bay, An experimental study determines the electrical contact resistance in resistance, Welding Journal, 85 (2005), 73-76

${ }^{16}$ Specification for automotive weld quality resistance spot welding of steel, AWS D8:1M, New York, American National Standard, 2007 